\title{
Shifts and continuities in Zulu personal naming practices
}

\section{Authors: \\ Sihawukele Ngubane ${ }^{1}$ Nompumelelo Thabethe ${ }^{2}$ \\ Affiliations: \\ ${ }^{1}$ Department of isizulu, School of Arts, Howard College Campus, University of KwaZulu-Natal, Durban, South Africa \\ ${ }^{2}$ Department of Community Development, School of Built Environment and Development Studies, Howard College Campus, University of KwaZulu-Natal, Durban, South Africa}

\section{Correspondence to:}

Sihawukele Ngubane

Email:

ngubanes@ukzn.ac.za

\section{Postal address:}

Mazisi Kunene Road, Durban 4041, South Africa

\section{Dates:}

Received: 13 Apr. 2011

Accepted: 14 Feb. 2013

Published: 19 Aug. 2013

How to cite this article: Ngubane, S. \& Thabethe, N., 2013, 'Shifts and continuities in Zulu personal naming practices', Literator 34(1), Art. \#431, 7 pages. http://dx.doi.org/10.4102/ lit.v34i1.431

\section{Copyright:}

(C) 2013. The Authors.

Licensee: AOSIS OpenJournals. This work is licensed under the Creative Commons Attribution License.

\section{Read online:}

It is widely accepted that, in all societies, personal naming practices and culture are intertwined. Given that culture is not static, but dynamic and ever changing, personal names have undergone a major transformation due to socio-cultural and political factors. This article reflects on shifts and continuities in the practice of personal naming amongst the Zulu people. Emerging data demonstrate the evolution from pre-colonial Africa to the post-1994 period in South Africa. It is further illustrated that the reclaiming of indigenous names in the new democratic dispensation is perceived as a way for Africans to re-define and re-affirm their identities, thus de-stigmatising their culture. Ultimately, this article makes a strong argument that personal naming, in any society, is not detached from the socio-cultural environment. Rather, personal naming and culture are inextricably linked to socio-political conditions at any historical moment. This is demonstrated in the shift from personal naming practices greatly inspired by communal values to those steeped in contradictions within the epoch of neo-liberal capitalism. It is, therefore, concluded that shifts in people's consciousness lead to fundamental shifts in personal naming practices.

Verskuiwings en kontinuïteit in persoonsnaamgewingspraktyke in die Zoeloekultuur. In alle gemeenskappe word dit aanvaar dat persoonlike naamgewingspraktyke en kultuur met mekaar vervleg is. Aangesien kultuur nie staties is nie, maar dinamies en voortdurend aan die verander, het persoonsname groot verandering ondergaan as gevolg van van sosio-kulturele en politieke faktore. Hierdie artikel besin die verandering en kontinuïteit in die praktyk van persoonsnaamgewing onder die Zoeloes. Nuwe data toon die ontwikkeling vanaf prekoloniale Afrika tot die post-1994 periode in Suid-Afrika. Dit toon ook dat die terugwinning van inheemse name in die nuwe demokratiese bedeling beskou moet word as ' $n$ wyse waarop Afrikane hulle identiteit herdefinieer en herbevestig; dus ' $n$ destigmatisering van hulle kultuur. Hierdie artikel neem sterk standpunt in dat persoonsnaamgewing in enige gemeenskap nie van die sosio-kulturele omgewing losgemaak kan word nie. Persoonsnaamgewing en kultuur is veeleer onlosmaaklik aan die sosio-politieke gegewenheid van 'n spesifieke historiese tydperk verbonde. Hierdie feit word gedemonstreer deur die verskuiwing van persoonsnaamgewingspraktyke wat grootliks deur gemeenskapswaardes geïnspireer was, na dié wat deurspek is met teenstrydighede van die tydperk van neoliberalistiese kapitalisme. Die gevolgtrekking word gemaak dat verskuiwings in mense se georiënteerdheid tot fundamentele verskuiwings in persoonsnaamgewingspraktyke lei.

\section{Introduction}

Whilst it is acknowledged that personal names are significant in all societies, Suzman (1994) maintains that this reality is more pronounced in African societies. The distinction between African and English personal naming practices is largely based on the motivation for naming (Lubisi 2002; De Klerk \& Bosch 1995). Hence, 'name meaningfulness continues to differentiate the naming patterns in African societies from Western naming practices' (Neethling 2003:56). Writing about Zulu personal naming practices, Suzman (1994) notes that:

Traditionally, personal names were unique and meaningful, emerging from circumstances at the time of the child's birth. Fathers and grandfathers were the namegivers. The giving of a name to a child had significance within the larger family, with the consequence that the child was rarely the focus of his or her name. (p. 254)

This assertion resonates with Lubisi (2002) and De Klerk and Bosch's (1995) viewpoints who both recognise the role of meaning as a distinct element in African naming practices. Essentially, 'in Western society, naming is primarily a system of reference, not symbolisation, and for English speakers, proper names typically differ notably from other words in their lack of sense or meaning' (De Klerk \& Bosch 1995:69). Therefore, choosing personal names in African societies are conscious decisions, rather than a random process. Parents or guardians bestow a personal name on a child that has social and cultural relevance and meaning (Neethling 2003). 
In conceptualising a personal name, Lubisi (2002) distinguishes between what he considers a given and an inherited name. A given name is bestowed at birth, whilst an inherited name is conferred at a later stage, and thus, fails to qualify as a personal name. Reflecting on his own personal experience, the author reveals that he was named Mafika on his birthday, 24 July 1962, yet a church minister later insisted on imposing a new name, Petros. After accepting this new name, his family was subsequently instructed that Petros had to 'become the first personal name as it was holy' (Lubisi 2002:119). Consequently, instead of being named Mafika Petros Lubisi, he remains Petros Mafika Lubisi to this day. The experience of the former President Nelson Mandela concurs with Lubisi's one. As revealed in the internationally acclaimed book titled, Long Walk to Freedom, Mandela's (1994:3) name Rolihlahla was bestowed on him at birth by his father. He remarks that, 'my more familiar English or Christian name was not given to me until my first day of school'. In analyzing this situation in relation to personal naming in Xhosa, Neethling (2003) asserts:

A Xhosa name and an English name is clearly a legacy of colonialism which was carried forward into the apartheid era when blacks remained in subservient positions and had no economic or political power. (n.p.)

The situation of the Zulus is not different. Lubisi (2002) alludes to the distinction between a personal name and what he considers to be a Christian or colonial name (inherited English name). In Neethling (2003:49) there is recognition that the Christian or colonial name is either 'a church name or a school name' as portrayed in the case of Lubisi (2002) and Mandela (1994). Suzman (1994:255) maintains that 'Zulu children have two personal names: their amagama asekhaya [home names], and their English or so-called school names', which in her definition, are both personal names. This article is based on Suzman's (1994) definition of a personal name.

Personal naming is viewed as a significant process of bestowing a name upon a child as a symbol of identity. In addition, Finch (2008) recognises that a given name has a dual role, that is, a personal and communal function. Accordingly, it is personal to an individual and differentiates between members of a group. At a collective level, it denotes social connections with one's family and the wider community. As Zohar and Marshall (cited in Ntuli 1999) write:

the main challenge of our time is to link the inner world of self with the outer world of society, and to see both within the larger context of the natural world. (p. 192)

Personal names originally aimed at achieving this purpose as they are significant in providing personal and cultural identities, preserving a people's identity and heritage and transmitting it from generation to generation, thus making names an extension of the structure of society.

Viewed in this way, personal naming is not a neutral process; instead it occurs in a socio-cultural environment that acts as a reflection of wider social changes (Suzman 1994). Ultimately, it can be assumed that personal naming practices are a social construction. For instance, parents may choose to give their child a name foreign to their culture, either because they like the foreign name (De Klerk \& Bosch 1995) or because it is politically and socially useful to have a foreign name as was the case in much of Africa, particularly during the colonial era. As reflected in the case of Lubisi (2002), most African people accepted 'Christian' names when they chose to be baptised into Christianity whilst others, out of respect for, or fear of, their masters, adopted their masters' names. Ntuli (1999:191) poignantly writes about this practice arguing that Eurocentrism is a cultural ideology that used Christianity in subtle ways to 'gain hegemony over the rest of the world'. In defining 'hegemony', a concept that is often associated with Antonio Gramsci, Brookfield (2005) states:

Ideology explains how the ideas of the ruling class become universalized as the ideas of all. Hegemony widens this understanding of ideology so that instead of conceiving it as a system of dominant ideas deliberately designed to reinforce the power of the ruling class, it can be viewed as embedded in a system of practices ... Ideology becomes hegemony when the dominant ideas are learnt and lived in everyday decisions and judgments and when these ideas (reinforced by mass media images and messages) pervade the whole of existence. (p. 94)

This discourse necessitates 'a detailed analysis of culture as ideology' (Ntuli 1999:189) that ultimately becomes 'a first target of colonial power' (Ntuli 1999:194). Against this backdrop, the article relies on the notion of Afrocentrism as a conceptual tool to foster counter-hegemonic discourses. Afrocentrism is premised on the understanding that all of life is interconnected as opposed to the Western binary mode of thought (Ntuli 1999). The concept of an African renaissance is one way of ensuring the application of the Afrocentric philosophy. African renaissance refers to an African rebirth, which for Mbeki (2004) constitutes an African identity that embraces the past, present and thus appreciates the interconnectedness of life. Ultimately, this gives rise to an African identity that encompasses a sense of black consciousness that is inclusive. This view is articulated by Mbeki (2004) who acknowledges that all the nations of the world that have settled in Africa have become part of who he is as an African. This point poignantly captures his sentiments, 'I am formed of the migrants who left Europe to find a new home on our native land. Whatever their own actions, they remain still, part of me' (Mbeki 2004:9).

The overarching objective of this article is to examine the impact of the transition from pre-colonial to the new democratic South Africa on personal naming practices amongst the Zulu people. The isiZulu speaking community is the largest grouping estimated at 10 million speakers in multilingual South Africa, followed by the isiXhosa speakers estimated at approximately seven to eight million speakers (Neethling 2003). This is a qualitative study that was conducted in both urban and rural areas in the province of KwaZulu-Natal, South Africa. A total of 120 participants were interviewed. Available literature was also reviewed, together with documents such as a local telephone directory. In general, this article highlights the three main phases within the context of naming practices: pre-colonial, colonial and post-colonial. In the pre-colonial period given names were indigenous; in the colonial and apartheid period people were obliged to adopt Western names; and in the post-colonial 
period this has been reversed and Western names have become secondary, with isiZulu names taking centre stage. It is therefore argued that personal naming practices within the Zulu nation have undergone significant changes owing to socio-cultural and political conditions across different periods in history. This view is succinctly articulated by Herbert (1997), who recognises a significant link between the evolution in naming and socio-cultural meaning.

The next section depicts characteristics and features of names in different periods to mark the effect of changes in the South African political landscape. It was concluded that for the African culture to be deeply grounded, a certain level of consciousness is required in the practice of personal naming.

\section{The transition from pre-colonial Africa to post-1994 South Africa}

\section{The pre-colonial period}

In the pre-colonial era, prior to the advent of missionary education, African people used indigenous languages for references and addressing each other (Ntuli 1999). Ethnic names were used because they defined members of the speech community. It is also through indigenous languages that culture and heritage is transmitted from generation to generation. Linked to personal naming practices is the fact that most Zulu names from the eighteenth to the twentieth centuries were derived from the daily experiences of families and communities. The records of Bryant (1929), as reflected below, reveal that the given names during this precolonial period were limited to isiZulu and did not include, what Lubisi (2002) deems Christian or colonial names. Bryant's (1929) records signify that names were given for a social reason, heavily influenced by life circumstances as reflected below:

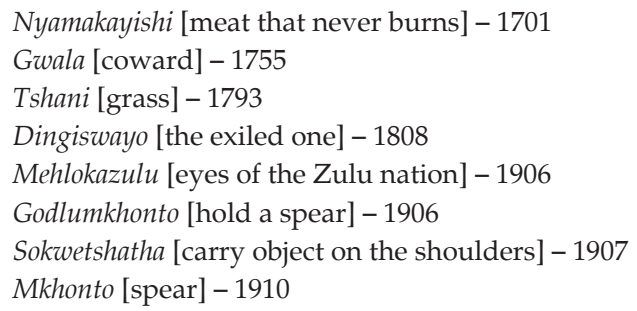

These record entries show that foreign names were not applicable in historical Africa as they had no practical relevance in indigenous communities. Agbontaen-Eghafona (2007) echoes this view by observing that, 'during the precolonial era, indigenous names were borne by the majority of the populace' (p. 106).

This pre-colonial era also presents another dimension in relation to Zulu personal naming practices. It suggests that most Zulu names recognised the genealogy of the family as indicated in Shaka kaSenzangakhona (Shaka son of Senzangakhona). Senzangakhona was Shaka's father, whom according to anecdotal evidence never liked his son due to fear that he would push him from the royal throne (Wylie 2006). Despite being regarded as an outsider, having grown up in exile as a wanderer, Shaka acknowledged and claimed his ancestry in Shaka kaSenzangakhona. This resonates with Ntuli's (1999) element of complementarity in the African worldview, which allows people to live comfortably with contradictions in their own lives. The author argues that this thinking 'can create conceptual violence if one is socialised into the Western binary mode of thought' (Ntuli 1999:185). The following are examples of other names from this period that appreciates the lineage:
Dingane kaSenzangakhona [Dingane son of Senzangakhona]
Nandi waseLangeni [Nandi from Langeni clan]
Mkabayi kaJama [Mkabayi daughter of Jama]
Dinizulu kaCetshwayo kaMpande ka Senzangakhona [Dinizulu of Cetshwayo, Mpande of Senzangakhona]
Mbophe kaMakhedama [Mbophe son of Makhedama]

The above names belong to women and men who marked the history of the Zulu nation and formed part of the genealogy of the Zulu lineage. All the names highlighted above had social meanings such as uShaka kaSenzangakhona. The name uShaka refers to a disease called itshaka 'a troublesome intestinal beetle' (Wylie 2006: 84), which led to 'a looseness of the bowels' (2006:85). When Shaka's mother's mysterious pregnancy was first reported, the Zulu clan claimed that she was suffering from itshaka because she fell pregnant out of wedlock. Senzangakhona received his name when his father remarked during his birth, 'You have done well, Nkosikazi [my wife], you have done well [wenze ngakhona] by producing a son for me' (Wylie 2006:78). Some of the names tend to predict the future. The name of $u$ Dingane, for example, may be interpreted in two ways, as the verb dinga, which means 'to be in exile' and 'to need something'. As events illustrated, Dingane eventually wanted the Zulu throne, and plotted to kill King Shaka. After King Shaka's assassination, Dingane succeeded him but he himself ended up having to give up the throne, and was hunted down to be assassinated, eventually dying in exile (Ntuli 1981). Mpande means 'root', and Mpande had many children and became the root of the Zulu royal family (Lubisi 2002). One of his sons, Cetshwayo [the one who is reported for wrongdoing], was the last Zulu king, reigning until the British government took control of the Zulu nation in 1879 (Wylie 2006). Some of his senior people spied on him for the British government as foretold by his name. People such as former President Nelson Mandela (1994) find it difficult to validate a claim that a name can define a person's destiny. Yet, he still reports, to many friends and family members, that the colloquial meaning of his name Rolihlahla [troublemaker], foretold his future and the many storms he 'caused and weathered' (Mandela 1994:3). It is the authors' view that foretelling in personal naming practices is one of the areas that is under researched in onomastics - the study of the history and origin of names.

\section{The colonial and apartheid period}

The colonial period in South Africa began in the nineteenth century under Dutch and British rule and continued into the apartheid period from 1948 to 1994. Reflecting on events that took place during this period, Ntuli (1999:193) concludes that, 'culture as a weapon for organising a people for effective domination can be demonstrated by both 
colonialism and apartheid'. The two periods are lumped together because they bear a number of parallels, particularly in their reliance on Christianity as machinery for subjugation of the black majority in South Africa. Instances of Zulu names in the colonial and apartheid eras blatantly express a shift from preserving the lineage observed in the pre-colonial period to an embodiment of the sovereignty of a Christian God as reflected in the following examples of amagama asekhaya [home names]:

Mandlenkosi [God's strength]

Nomthandazo [Prayer]

Bonginkosi [Praise God]

Dumisani [Praise God]

As Ntuli (1999) points out:

Christianity was used as a subtle battering ram to gain hegemony over the rest of the world. It portrayed a religious system based on perfection. A perfect God against pagan gods. A perfect Jesus Christ. Perfect angels and saints. The Virgin Mary as a paragon of perfection with her immaculate conception. (p. 191)

It was therefore within the colonial period that European settlement and European socio-political domination led to names becoming an expression of the political interaction between the colonisers and the colonised through the process of acculturation. The dominance and perceived superiority of the British culture affected African naming practices. Reflecting on the impact of colonialism in Gabon, NdingaKoumba-Binza (2011) concurs that westernisation influenced naming practices. Moyo (1996) claims that the reasons Africans were given European and Christian personal names were that their previous names were perceived as complicated, foreign or heathen. Mphahlele (1972) elaborates:

During the era of colonialism Africans were denied all rights and were considered big children who needed training for a new lifestyle. Africans were denied any reference to their own past. For the coloniser, the African's real life and history starts from the time of the coloniser's arrival. (p. 19)

Agbontaen-Eghafona (2007) corroborates Mphahlele's assertion with observations of his own: 'Foreign names used alongside indigenous names became popular with the introduction of Christianity and colonial rule in the early twentieth century'. (p. 106)

Lubisi (2002) added that Christian or European names were imposed on Black people to facilitate colonial administration, since most English-speaking missionaries could not pronounce indigenous names. Similarly, Ntuli (1999:191) points out that, 'mission schools forbade the natives the use of "their" language', thus schools recognised only names that were constructed in English. In his autobiography, President Nelson Mandela supports with Ntuli's claim that under British administration, children were given English names at schools because, 'whites were either unable or unwilling to pronounce an African name, and considered it uncivilised to have one' (Mandela 1994:13). These assertions are consistent with the findings of this study, namely that people who were born during the colonial period were given names such as John, James, Samson, Peter, Petros, Mary, Moses, George,
Ruth, Florence, Norah and Miriam which appeared in official documents and yet were not used for social purposes. It was reported that when non-Christian children (those not baptised and consequently lacking Christian or Western names) were registered at school, they were told to find out from their parents whether or not they had a school name. If the parents had not previously registered a school name, they were compelled to choose one - unless they were prepared to have someone else make an arbitrary choice on their behalf. The English names, insisted upon by the authorities, were used almost exclusively for school and administrative purposes. In a study conducted amongst Xhosa people, Neethling (2003) reports that some of the respondents displayed a negative attitude towards English names as they associate them with slavery.

The changes in Zulu personal naming practices are further reflected in the dual-naming of Zulu kings born in the colonial era. As indicated earlier, Zulu kings had only isiZulu names during the pre-colonial period, but in subsequent periods a second English name also featured. These examples signify a shift in naming practices amongst the Zulu kings:

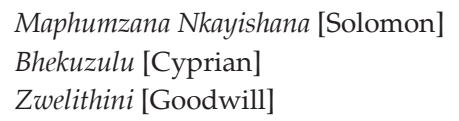

In the mid-twentieth century, Africans started to voluntarily bestow English names on their children that reflected the meaningfulness of African personal naming. Consequently, names such as Patience, Precious, Lucky, Faith, Pretty, and Joyce became commonplace. It is against this backdrop that Suzman (1994) contends that names have a tendency to reveal the era in which a person was born. This resonates with the findings of the study, which suggest that a name such as 'Josephina' is not popular amongst Zulu children born in the democratic South Africa. Rather one would find English names such as 'Hope' and 'Freedom'. This observation reinforces Herbert's (1997) claim that children born after 1990 have names associated with political liberation in South Africa. What these categories of names reveal is that although parents wanted contemporary names bestowed on their offspring, they also wanted them to reflect meaning and social relevance.

Personal naming practices in the apartheid era remain similar to experiences in the colonial period in the sense that children had two personal names: 'their amagama asekhaya 'home names', and their English' names. (Suzman 1994:255). However, emerging findings indicate that personal naming practices that applied amagama asekhaya [home names] in the apartheid era were slightly different from those reflected in the pre-colonial and colonial period. On the one hand, the national government had legitimatised Christianity at the expense of all other religions, whilst on the other hand, people's political consciousness was higher than observed in the colonial period. In light of this reality, Western and European cultures persistently found their expression in Christian values and beliefs during the apartheid period. 
At the same time, local people were able to express their sentiments in personal naming practices as a tool for social change. Examples of names characteristic of the liberation struggle and the quest for democracy in South Africa are the following:

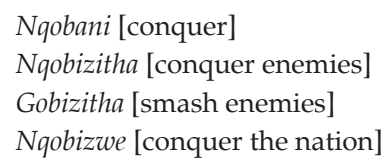

It can therefore be understood that what makes personal naming practices distinct in the apartheid era is the integration of the autonomy observed in the pre-colonial era with Christian values noted in the colonial period. Put differently, this era merged and embraced two periods in history to generate diverse personal naming practices that are still largely influenced by a two-tier personal naming system (home and school or church name), which began in the colonial period. Nevertheless, the apartheid period was characterised by a renewed consciousness that personal naming practices were the responsibility of families.

\section{The democratic South Africa}

The democratic South Africa post-1994 is deeply rooted in the culture of human rights. The South African constitution affords people a right to bestow a personal name of their choice upon their children. Names of all languages are acceptable in schools, churches, hospitals and government administration as formal and official names. As shown in Neethling's (2003) study, personal naming amongst Xhosa people in recent years is predominantly limited to African languages. This resonates with our findings, which suggest that the majority of children born after 1990 have isiZulu names only such as:

Mandisi Nosihe
Ntandoyenkosi Zamabomou
Lindani Lwazi
Sabelo Bandile
Sinenhlanhla Sthandiwe
Lungelo Njabulo

Yet, Ntuli (1999) poignantly points to the challenge of the present moment, which is often termed the post-apartheid period, arguing that the prefix 'post' will continue to haunt us. 'This signifier points to the continuation of the past, reinscribing itself in the present, while struggling to reconcile the two moments' (p. 185). In the context of Zulu personal naming practices, for example, the centre of power keeps shifting, yet fails to highlight collective interests observed in the pre-colonial era. A diachronic observation of Zulu personal naming practices shows a shift from traditional to Christian or colonial names and a shift back to traditional naming practices after 1990. However, evidence suggests that the shift back to African names during the transition takes place under different socio-cultural and political conditions. For instance, it is noted that significant changes in personal naming practices ensue in two ways based on the philosophy of the African renaissance and/or contemporary trends. This section elaborates on this paradox.

\section{Name changes based on the philosophy of the African renaissance}

It was established that the older generation of public politicians were born in the colonial and apartheid period. Thus, they have amagama asekhaya [home names] and English names, with most of them known by their English names pre1990. In the new democratic South Africa, they have restored the use of African names as a way of asserting their African identity, whilst simultaneously retaining their English names. These findings are consistent with observations that suggest that politicians 'now prefer their African names as opposed to the Christian (colonial) ones' (Lubisi 2002:121). Examples emanating from the study include, amongst others, the following political figures:

Winnie Madikizela-Mandela [Nomzamo] - $1936^{1}$ - Nelson Mandela's ex-wife

Franscisca Shabalala [Nomvuzo ${ }^{2}$ - Deputy Mayor at eThekwini Municipality

Desmond Tutu [Mpilo] - 1931 - Nobel Peace Laureate in 1984

Nelson Mandela [Rolihlahla] - 1918 - Ex-President of South Africa

Similarly, Lubisi (2002) records the following politicians who also chose to change their names after 1990:

Arnold Stofile [Makhenkesi] - 1944 - Ex-Minister of Sports and Recreation

Samuel Shilowa [Mbhazima] - 1958 - Leader of COPE (political party)

Shepherd Mdladlana [Membathisi] - 1952 - Ex-Minister of Labour Patrick Lekota [Mosiuoa] - 1948 - Leader of COPE (political party) (p. 121)

It needs to be noted that this is an era that is fraught with contradictions. On one level, people's consciousness of the significance of amagama asekhaya [home names] is high. On another level, name changes do not necessarily translate into lifestyle changes in fundamental ways. Put differently, whilst the false dichotomy between private and public names is slowly fading, a culture that integrates the inner world of self with the outer world of society is not yet evident in personal naming practices. Name changes in this period do not necessarily lead to the critical consciousness that existed in the pre-colonial period. It is for this reason that some study participants, born in the colonial and apartheid period, expressed a disinterest in prioritising indigenous names at this point in time. They argue that what is required is a South African citizen with a sense of self and public awareness as observed in people like former President Rolihlahla Nelson Mandela. He is an international icon known throughout the world, yet, he chose to retain the colonial English name Nelson post-1994. It can be deduced that the mere restoration of a home name alone is not a panacea for cultural transformation. This view resonates with the Afrocentric paradigm, which argues for the interconnectedness of life. In analysing this integration, Ntuli (1996) asserts that the African worldview is able to hold two opposites, such as death and life, in harmony and balance. It is in this context that Mbeki (2004) recognises that Africans have to find ways 1.Denotes a date of birth.

2.Birthdate unknown. 
to define themselves in this historical moment because an African identity is not either/or. Rather, it is rooted in understandings that appreciate that the past, present and future are intertwined to generate contemporary African identities. Equally important is the urgent need to realise that although modern day Africans cannot go back to the pre-colonial age, nevertheless, they can utilize the principles of that period for guidance as expressed in the element of Ubuntu (Ntuli 1999). To this end, a truly transformative process will not limit itself by reinstating amagama asekhaya [home names], but will go further to ultimately integrate such changes with the African value system as opposed to the consumerist culture. As Lewis (2004:47) argues within the context of African renaissance, 'Africa needs leaders in which their words and acts are inextricably linked'. Mandela is one such leader whose integrity, in the quest for socio-economic justice, is undisputed.

\section{Name changes based on contemporary trends}

A number of underlying factors give rise to personal naming practices that are influenced by contemporary trends in the context of human rights and neo-liberal capitalism. More and more people are starting to prioritise diversity and personal choice within the secular post-apartheid South Africa. The women empowerment discourse, for example, has resulted in more women becoming name-givers whereas in the past only males had the right to name their children. Moreover, the reality on the ground indicates that women are heads of most households, thus fathers and grandfathers have lost their name-giving prerogative (Suzman 1994).

It is further noted that in some instances, personal names are given to children purely at the discretion of the namegiver, without reference to meaning or association, and in compliance with modern tastes. This practice is associated with names that have a pleasant, melodious sound, and is more common in urban than in rural areas. As De Klerk and Bosch (1995:79) observe, there is a growing tendency for parents to bestow names on their children just because 'they liked the name or its sound - a view rarely encountered in earlier studies on African naming practice'. For example, names that start with a vowel have become a fashionable trend since 1994 as articulated in the following examples:

Aphethe [they are in cha
Aphiwe [we have been give
Aphelele [we have had e
Amahle [beautiful ones]
Elihle [beautiful child]
Esihle [beautiful gift]
Owami [mine]
Owethu [ours]
Olwethu [our love]

The names in this category tend to portray contesting identities. They certainly reveal that a certain level of consciousness of an African identity exists. Furthermore, it is noted that some of the names are suitable for both sexes 3. Names in this category with a vowel 'o' are unisex. and this presupposes that democracy is marked by radical name changes. In the same vein, these personal names embody values that contradict the African worldview, which is rooted in the philosophy of Ubuntu (Ntuli 1999). The names that begin with a vowel tend to assert personal choice based on individualistic interests within the democratic South Africa. Suzman (1994:254) earlier alluded to the fact that in the past, 'the child was rarely the focus of his or her name'. Additionally, Finch (2008) alludes to the dual role that a name bears: a personal and societal function. However, there is a shift in Zulu personal naming practices in postapartheid South Africa that perpetuates a focus on the self. This is particularly evident in latter names with a vowel 'o' as reflected in names such as Owami [mine], Owethu [ours] and so forth. These names portray contemporary cultures which embrace individualist interests and a sense of detachment from the outside world. Ultimately, this naming practice occurs in a socio-cultural environment characterised by self-interest within the context of globalisation.

As mentioned earlier, in the pre-colonial period personal naming practices were linked to social events and family ancestry. In the colonial and apartheid period, the notion of a Christian God shifted to the centre of personal naming practices in multiple ways. What makes the democratic post-1994 period peculiar is its promotion of human rights embedded in a consciousness of globalisation through the mass media. Whether such developments are progressive or not warrant another study.

Clearly, the political changes in South Africa influence attitudes towards the choice of names. This is a reminder of the evolution in personal naming practices amongst the Zulu people that happened within a specific socio-political context. Comparatively speaking, the names alluded to earlier in the pre-colonial period are all-encompassing. Contemporary trends frequently lead to the adoption of Western practices into African culture, apparently in the belief that such borrowed practices are indicative of sophistication. Clearly, Western influence from the colonial to post-colonial Africa is a prominent feature. In light of this reality, Ntuli (1999:189) asserts that pre-colonial Africa is a period that can guide us in producing a 'counter-hegemonic discourse' in the process of re-claiming the first principles. It can therefore be argued that personal naming practices are under threat in situations where they have been shifted from family systems to be regulated by a capitalist consciousness which foster individualism.

\section{Discussion and conclusion}

This article illustrated the shifts that have taken place in personal naming amongst the Zulu people. The findings generally demonstrate that, previously, personal names were in the isiZulu language, with socio-cultural meanings and reasons attached to them. During the colonial and apartheid period, naming practices changed to include English or colonial names and those foreign to the Zulu people. In post1994 South Africa, many Africans insisted on reconstructing 
their identities by reclaiming features of names that speak to their African heritage and history. Consequently, most people bearing Western names reinstated their African names. Moreover, it has become common practice for children born post-1994 to have African names only bestowed at birth, as opposed to the two-tier personal naming system evident in colonial times. There have been major shifts in people's consciousness across the different periods; yet, Western influences on Zulu personal naming practices stubbornly persist from the colonial to the post-apartheid South Africa. Steeped in contradictions, the socio-cultural environment keeps shifting from traditional to Western and back to traditional personal naming practices. Although both the pre-colonial and post-colonial periods primarily focus on the use of African names, people's consciousness within the two contexts is full of ambiguities. The modern day South Africa continues to be a victim of Western imperialist interests, thus producing contested identities in personal naming practices, whereas the pre-colonial period remains intact from Western powers. Western thought, which Ntuli (1999) views as a culture ideology, requires an analysis based on the African worldview to generate counter-hegemonic discourses. The presumed African worldview of the precolonial period is clearly asserted in people's practice to give names in indigenous languages that elucidate communal values and the interconnectedness of life. Although Zulu speakers in post-apartheid South Africa also largely relies on Zulu names, people's consciousness is totally different, so that societal values are either misrepresented or absent in personal naming practices.

Against this backdrop, critical consciousness in the analysis of what happens in society requires Africans to move beyond name changes; to also re-evaluate and re-appropriate their values and traditions. The study has shown that a Zulu name in itself is not a panacea for social transformation; therefore, it is argued that the rhetoric on Zulu naming practices should embody African values. The adoption of Zulu names that fail to translate into genuine social transformation and life-nurturing lifestyles ultimately fail to depict the African philosophy of Ubuntu. In the same vein, it also needs to be noted that since culture is dynamic, it can be expected that personal naming and names rooted in such societal change will themselves change to the extent that new names might be created for new experiences. Seeing that the aspect of motivation is key in Zulu personal naming practices, a question to be interrogated in future studies is whether parents in the post-apartheid period are conscious of the socio-cultural meanings attached to their motivation. Whose culture counts in Zulu personal naming practices? Until Africans develop a critical consciousness to engage with the impact of the socio-cultural and political environment in which personal naming practices evolve, there can be no deeply-grounded consciousness of an African identity.

\section{Acknowledgements Competing interest}

The authors declare that they have no financial or personal relationship(s) which may have inappropriately influenced them in writing this article.

\section{Authors' contributions}

S.N. (University of KwaZulu-Natal) and N.T. (University of KwaZulu-Natal) contributed equally to the writing of this article.

\section{References}

Agbontaen-Eghafona, K.A., 2007, 'Factors in personal naming and name change in postcolonial Southern Nigeria', Nomina Africana 21(1\&2), 105-125.

Brookfield, S.D., 2005, The power of critical theory, Jossey-Bass, San Francisco.

Bryant, A.T., 1929, The olden times in Zululand, Shuter and Shooter, Pietermaritzburg.

De Klerk, V. \& Bosch, B., 1995, 'Naming in two cultures: English and Xhosa practices', Nomina Africana 9(1), 65-85.

Herbert, R.K., 1997, 'The politics of personal naming in South Africa', A Journal of Onomastics 45(1), 3-17.

Finch, J., 2008, 'Naming names: Kinship, individuality and personal names', Sociology 42(4), 709-725. http://dx.doi.org/10.1177/0038038508091624

Lewis, R., 2004, 'Discussant: I am an African by Thabo Mbeki', African Renaissance 1(2), 47-48.

Lubisi, P.M., 2002, 'A glance into African personal names', Nomina Africana 16(1\&2), 118-124.

Mandela, N., 1994, Long walk to freedom: The autobiography of Nelson Mandela, Little, Brown and Company, London.

Mbeki, T., 2004, 'I am an African', African Renaissance 1(2), 5-13.

Mphahlele, M.C.J., 1972, 'The Methodist Venture in Education at Kilnerton 1886-1962', Master's thesis, School of Education, University of the North, Turfloop.

Moyo, T., 1996, 'Personal name and naming practices in Northern Malawi', Nomina Africana 10(1\&2), 10-19.

Ndinga-Koumba-Binza, H.S., 2011, 'From foreign to national: A review of the status of the French language in Gabon', Literator 32(2), 135-150. http://dx.doi.org/10.4102/ lit.v32i2.15

Neethling, B., 2003, 'Perceptions around the English name of Xhosa speakers', Nomina Africana 17(2), 47-65.

Ntuli, F.L., 1981, Umbuso ka Shaka, Mariannhill Mission Press, Pinetown.

Ntuli, P.P., 1999, 'The missing link between culture and education: Are we still chasing Gods that are not our own?', in M.W. Makgoba (ed.), African Renaissance: The new struggle, pp. 184-199, Mafube Publishing, Johannesburg/Tafelberg Publishers, Cape Town.

Suzman, S.M., 1994, 'Names as pointers: Zulu personal naming practices', Language in Society 23(2), 253-272. http://dx.doi.org/10.1017/\$0047404500017851

Wylie, D., 2006, Myth of iron: Shaka in history, Ohio University Press, Athens, $\mathrm{OH}$ 